urine in the early stages and the cardiac sounds were muffled, especially the aortic systolic. With treatment these advanced cases got relief, but death usually claimed them after their third relapse. The nerve changes were noticeable in the early stages by their absence.

The post-mortem examination revealed an abundance of yellowish subcutaneous fat, an increase of serous fluid in the serous cavities, more particularly the pleural and pericardial, and in the latter it was richly pigmented. The heart was dilated and flabby, and exhibited fatty degeneration to a marked degree and was loaded with fat, and milk patches were common on the front wall of the left ventricle. The endocardium was pale and fatty. The valves were normal and clots-pale and gelatinous-existed in the auricles. The blood was very fluid and dark and the sternal marrow was soft, oily, and sanguineous. The lungs were congested and the liver was enlarged, very friable, and exhibited chronic venous congestion and fatty changes; no waxy degeneration. Bile was increased and thickened and the gall-bladder walls hypertrophied, and in many cases flint-like facetted calculi were common. The stomach was dilated and there was a great deal of emphysematous fatty tissue around the kidneys; the capsule easily stripped off and on section they showed fatty changes and venous congestion; the Malpighian bodies were prominent, pointing to a condition of parenchymatous nephritis. The spleen was enlarged and fatty and covered all over with fatty peduncular growths, and it cut like cheese, was very dark purple as if severely congested, and the trabeculæ were very prominent and of a pale colour. The pancreas seemed normal.

From the above it will be seen that there are many points in common in beri-beri with scorbutus and post-anæsthetic poisoning or fatty acid intoxication arising from faulty glycogenesis and disordered tissue metabolism.

I am, Sir, yours faithfully

JAMES MONTEITH, M.B., C.M. Edin.

Oldham, Sept. 25th, 1908.

\section{THE PREVENTION OF TUBERCULOSIS (IRELAND) BILL.}

Io the Editor of THE LaNceT.

SIR,-I have read the letter of Dr. J. C. McWalter in your issue of Sept. 19th, to which I take grave exception and on which I beg to join issue. Dr. McWalter says: "Knowing what I do of the Irish people I believe that the compulsory notification clauses will excite so much suspicion and dread as effectually to undo any good result heretofore obtained from the tuberculosis campaign." That is Dr. McWalter's opinion; but as it is a forecast of what he thinks will happen in the future to a movement which he fully recognises "has done much good," I do not feel bound to vie with him in the rôle of prophet of evil. "The evil which men do lives after them," but in this instance I hope that the good which has been admittedly done by Lady Aberdeen and those who have had the honour and the privilege of working with her in the anti-tuberculosis movement in Ireland will live and extend. Dr. MIcWalter says that the movement "has a source of weakness in not being controlled by those in close touch with the popular party." Is Dr. McWalter entitled to speak for the popular party? Is he in close touch with that party? Whom does he desire to place in control of the movement which he admits has accomplished so much good? I am of the popular party. So far as I know I am not quite out of touch with it. I know the feelings, the hopes, the fears, the aspirations, aye, even the prejudices of our people as well as Dr. McWalter. I have been north and south and east and west from no selfish or sordid motives. Like others in the movement, I have been willing to sacrifice time and ease and convenience to try and do something towards saving our perishing people. Dr. McWalter tells us of his success in dealing with public boards in Dublin, because they are satisfied that "he is acting unselfishly." "But," he adds, "members of such boards are prone to suspicion; and it is difficult to assure them that a practitioner is entirely unbiassed if he advocates a system which nill put half-erowns in his pocket, whilst it impales for life the person notitied." I protest most strongly against this unworthy and unwarrantable suggestion of Dr. McWalter. It strikes at the honesty and integrity of the members of our profession in Ireland and impugns the motives of those who are acting, as they believe, for the public good without hope of fee or reward. Their conduct is as unselfish and as free from taint of unworthy suspicion as Dr. McWalter's. The question is too urgent, the issue too grave, to be brushed aside in deference to prejudices or suspicions which, if they exist, are ill-founded and baseless, and which educated and enlightened public men like Dr. McWalter should endeavour to combat and overcome, not foment and foster.

I am, Sir, vours faithfully,

Michaec F. Cox, M.D. R.U.I., F.R.C.P. Irel., M.R.I.A., Dublin, Sept. 21st, 1908. Physician to St. Vincent's Hospital.

\section{To the Ealiter of THE LANCET.}

SIR, - I feel constrained much against my will to break $a$ lance with Dr. McWalter over his attitude towards the above Bill. As a member of a sanitary authority he is no doubt in close touch with the prejudices of those who will be most largely affected and must be therefore fully aware how necessary it is not to do or say or write anything that will strengthen or accentuate those prejudices. The Bill has been framed by the Irish Local Government Board with the obvious desire to interfere as little as possible with the un. fortunate subjects of the disease and only those provisions of the Infectious Disease (Prevention) Acts which are absolutely necessary to safeguard both the patients and the public are made applicable to tuberculosis. Whilst the Scottish Local Government Board unhesitatingly expressed its opinion that tuberculosis as an infectious disease could be added to the list of notifiable diseases under the 1889 Act and urged sanitary authorities to make applications to them for that purpose, the English and Irish boards absolutely refused to yield to the supplications of certain of their sanitary authorities on the ground that, if such were done, all the pains and penalties that attend the notification of such diseases as scarlatina, small-pox, and diphtheria would be exercisable against notified cases of tuberculosis. In consequence of the enormous amount of public feeling that has been aroused on this question and in response to the almost universal demand on the part of public representative bodies in Ireland, the Irish Local Government has introduced a Bill so framed as to make tuberculosis a notifiable disease and at the same time avoid even the appearance of harshness or official interference. In order to have a proper knowledge of the existence and prevalence of the disease which is essentially necessary if we are to cope with it successfully the first thing is to get information as to its whereabouts. And this can only be obtained by a system of notification, and under the system formulated in the Bill there is not the slightest excuse for any. one, much less one possessed of the legal acumen and mental calibre of Dr. McWalter, to suggest that there is the least probability of any person being treated as a leper or in any respect avoided either in his home or workshop. The bugbear about expense is also a mere shadow: outside the large cities the half-crowns that will gravitate to the pockets of the medical profession will be inconsiderable and will, I hope, in a few years reach vanishing point. When Dr. McWalter says the anti-tuberculosis movement in Ireland has an inherent source of weakness in not being largely controlled by those in close touch with the popular party I must confess I cannot understand what he means. No similar movement ever had such united and general support. It brought together men and women of all classes and creeds and all shades of politics. It collected on one platform the clergy of all denominations; professional men vied with each other in their efforts to acquire and dispense information, and, in fact, the whole country was alive with enthusiasm. However, Dr. McWalter thinks we should "go gently." We have been going gently for the past 30 years and what has been the result? We are in sanitary matters at least 30 years behind either England or Scotland. The English Public Health Act dates from 1875, the Irish Act from 1878; both are framed on exactly the same lines, and in addition the Irish Act established a complete system of medical officers of health by making all the dispensary doctors health officers for their respective districts. Instead of carrying out the intentions of the Act and calling upon the sanitary authorities to combine and appoint medical superintendent officers of health the then Local Government Board adopted the very 
same principle and for the very same reasons of moving gently, with the result that we are as we are. In Ireland we have tremendous leeway to make up in matters pertaining to sanitation, and the progress of tuberculosis in the three countries shows this more than anything else. It might have been different had even a minority of the sanitary authorities had the advantage of the presence and assistance and encouragement of such men as representatives of the ratepayers as Dr. McWalter, but unfortunately they had not, nor are they likely to have, so that it is absolutely hopeless to expect many boards to follow in the wake of the South Dublin board of guardians, and if we are content to adopt this method I would just like to ask the learned doctor how long does he expect it would take to reduce the mortality from tuberculosis from $2 \cdot 7$ to 1.35 and how many people would succumb to it in the meantime? I am, Sir, yours faithfully,

Samuel AgNew, M.A., M.D. R.U.I., Lurgan, Sept. 21st, 1908. Medical Superintendent Officer of Health, Lurgan.

\section{To the Editor of THE LANCET.}

SIR,_-"For the love of heaven, gentlemen," said Jowett to some cocksure junior Fellows one day, "conceive it possible that you may be mistaken." "With profound humility I submit the advice to Sir John Byers and to the other distinguished men who laud compulsory notification of tuberculosis as the most important step towards ridding Ireland of that plague.

But let me reply to Sir John's points. He inquires, are not the many meetings which have been held under Lady Aberdeen's campaign-in which compulsory notification was commended - a proof of the desire of the country for that step? I deny the conclusion; al the meetings were composed of three classes-those attached in one way or other to the Viceregal Court, some extremists on the medical side who had never studied the economic problem of providing for the phthisical, and a residue of well-meaning people who had never considered what compulsory notification really means. The whole business had such a philanthropic aim, and was indeed so well intended, that nobody cared to raise objections, but when as a result of these mutual admiration meetings an effort is made to pass penal legislation for a whole country it is time to protest.

Sir John Byers refers me to the experience of compulsory notification at Sheffield, New York, and elsewhere. I am not sure if Sir John was at the Sheffield meeting of the British Medical Association, but everyone could see that compulsory notification may be an excellent thing in a city where a whole population works together in crowded factories, and a doubtful experiment for a whole country where the conditions are absolutely different. If Sir John can point out any entire country where compulsory notification of phthisis prevails and causes no hardship we must be impressed by it, but the example of an odd city goes for nothing. The fact that in 1864 the Irish death-rate from tuberculosis was the lowest in the three kingdoms, although no sanitary precautions were heard of, whereas now, after a quarter of a century's sanitary legislation, it is the highest, gives one to think furiously about the net result of these measures in actual practice.

I am, Sir, yours faithfully,

Dublin, Sept. 27th, 1908. J. C. MCWALTER.

\section{"SENSATIONAL JOURNALISM." To the Editor of THE LANCET.}

SIR,-The prominence of "tragic deaths," "murders," and "suicides" in our daily papers is appalling. Every day when one picks up the morning newspaper and opens it at the summary and leading articles one's eye cannot fail to be attracted by the large letters on the same page stating reports as above. Such reading, to those of nervous temperament, weak-minded, and neurasthenic, is more than harmful, as it dictates to them the ways and means of acting likewise, and many, I think, have knowledge put into their minds upon which they act sooner or later.

When I was a lad in 1870-1880, or a quarter of a century ago, such reports were seldom seen or heard of. Now such statements are passed from mouth to mouth, in the motor, train, or tramcar, and appear to be the topic of the day and hour. Could not these horrors be hidden away discreetly on another page and many details omitted altogether? Surely the medical profession ought to try to see what can be done to rectify matters, thereby helping the weakminded and preventing atrocities being committed. It is as much the doctor's duty to prevent, when possible, sickness as it is to relieve and cure it. I write from experience, as lately patients of mine on reading the papers, and it is difficult not to let them get them, have been advanced from the subacute to acute stage of suicidal mania.

I am, Sir, yours faithfully,

Buxton, Sept. 25th, 1908. JoHN MCOSCAR, L.R.C.P. Lond

\section{RUPTURE OF THE LIGAMENTUM PATELLÆ. \\ To the Editor of THE LANCET.}

SIR,-O On looking over the last few numbers of The LANCET I see that in the issue dated Sept. 12th you have an annotation on two cases of rupture of the ligamentum patellæ, which is followed, in the issue of Sept. 19th, by a letter from a Leicester correspondent reporting another case. These have prompted me to send you notes of the following case which occurred on board of a mail steamer of which I was surgeon at the time.

The patient was a man aged 23 years. On June 19th, 1908, one day out from Punta Arenas, he slipped on the wet deck in a heavy seaway and fell, striking his left knee, he thought, against a steam-pipe. $\mathrm{He}$ said that he had a good deal of pain at the time but was able to get up and limp slowly along the deck. He did not come to me nor send for me till the next day, when he came to the dispensary and gave me the above history. His complaint was that "he could not straighten his knee." He did not complain of pain. On examining him, I found that there was a moderate degree of swelling over the front of the knee-joint; the swelling was not tense, but was tender, though only slightly. The tubercle of the tibia was uninjured. The patella was also apparently uninjured, but was very high up. It was freely moveable and movement did not cause pain. Below it there was a gap, which was partly filled up by the swelling over the front of the joint. He was absolutely unable to extend the leg. I made a diagnosis of rupture of the ligamentum patellæ and put up the limb on a posterior splint, with downward traction on the patella and a firm bandage over the joint. On our arrival at Valparaiso on June 26th I sent him ashore to the Hospital San Juan de Dios, where he was under the care of Dr. Page. On June 30th Dr. Page operated, turning up a flap in front of the joint. The ligamentum patella was found to be almost completely torn across, only a few fibres remaining undivided, and these showed evidences of having been stretched. The torn ends were approximated by strong chromicised catgut sutures, and the limb was put up in the extended position on a posterior splint. Unfortunately, I am not able to give any particulars of the result of the operation, as the wound had not been dressed by the time we sailed from Valparaiso, and I have not yet heard that the patient has returned to England. If it will be of interest to your readers, however, I will be glad to communicate the result as soon as I learn what it is.

I regarded the rupture of the ligamentum patellæ as being due to the sudden, forcible contraction of the quadriceps extensor and not to a blow from the steam-pipe. This opinion was shared by Dr. Page and Dr. J. C. Atkinson, as at the operation there were no evidences of bruising of the skin.-I am, Sir, yours faithfully,

South Shields, Sept. 27th, 1908. A. H. MACCOLL ROBERTSON.

\section{MEDICAL DEFENCE UNIONS.}

\section{To the Editor of THE LANCET.}

SIR, - In reply to the letter of " Practitioner" published in your issue dated Sept. 26th may I be allowed to state that there is one Medical Defence Union in England, of which I am general secretary, with offices at 4, Trafalgar-square, W.C., and that I shall be pleased if he will communicate with me and I will forward him full particulars. There is also the "London and Counties Medical Protection Society," Dr. Hugh Woods secretary, doing similar work, the office of which company is in Craven-street, Strand.

In respect to insurance offices covering similar ground I 